African Crop Science Journal by African Crop Science Society is licensed under a Creative Commons Attribution 3.0 Uganda License. Based on a work at www.ajol.info/ and www.bioline.org.br/cs DOI: https://dx.doi.org/10.4314/acsj.v29i4.3

\title{
ENDOPHYTIC FUNGI ASSOCIATED WITH FOUR ENDEMIC WILD COFFEE SPECIES (Mascarocoffea) IN MADAGASCAR
}

\author{
A.J. ZANANIRINA ${ }^{1,2}$, B.M. IACOMI ${ }^{3}$, D.A.D. RAKOTO-RANOROMALALA², I. RATSIZAFY ${ }^{1}$, \\ A.T.E. RAZAKATIANA ${ }^{1}$, M.D. ANDRIANANDRASANA ${ }^{1}$, R.H. BAOHANTA ${ }^{1}$, \\ N. RAKOTOARIMANGA ${ }^{1}$, H. RANDRIAMBANONA ${ }^{1}$ and H. RAMANANKIERANA ${ }^{1}$ \\ ${ }^{1}$ Centre National de Recherches sur l'Environnement, BP 1739 Antananarivo, Madagascar \\ ${ }^{2}$ Mention Biochimie Fondamental et Appliquée, Université d'Antananarivo, BP 906 \\ Antananarivo, Madagascar \\ ${ }^{3}$ Département Phytopathologies, Université des Sciences Agronomiques et Médecines Vétérinaires \\ de Bucarest, Roumanie \\ Corresponding author : jeanettejeff@gmail.com
}

(Received 17 December 2021; accepted 23 December 2021)

\begin{abstract}
Mascarocoffea are wild coffee plants endemic to Madagascar. These plants produce diverse, often specific biomolecules that are not found in cultivated coffee plants. Production of these compounds could be due to interactions between the endophytes and the host plant. Few studies have been carried out on the richness and diversity of microorganisms associated with these coffee plants. The objective of this study was to identify endophytic fungi isolated from the leaves of species of Mascarocoffea by morphological and molecular methods. Fifteen taxa were morphologically identified among the 30 isolated. These included Phyllosticta sp., Colletotrichum sp., Daldinia sp., Diaporthe sp., Cladosporium sp., Fusarium sp.01, Fusarium sp. 02, Fusarium sp. 03, Monilinia sp., Trichoderma sp., Alternaria sp, Penicillium sp., Aspergillus niger, Rhizopus sp. and Nigrospora sp. The phylum Ascomycota was the most represented, with 14 taxa and 1 taxon (Rhizopus sp.) belonging to the phylum of Zygomycota. Molecular characterisation confirmed of the identity of these 15 taxa and those of the morphologically Unidentified (NI) mycotaxa including Colletotrichum karstii, Colletotrichum siamense, Neofusicoccum parvum, Colletotrichum siamense, Punctularia strigosozonata, Stemphylium solani, Phoma multirostrata, Calophoma complonata, Daldinia vanderguchtiae, Phoma exigua and Boremia exigua. This study allowed us to identify the endophytic fungi isolated from Mascarocoffea leaves from Madagascar.
\end{abstract}

Key Words: Diversity, endophytic fungi, Madagascar, Mascarocoffea 
Les Mascarocoffea sont des caféiers sauvages endémiques de Madagascar. Ces plantes produisent des biomolécules diversifiées, souvent spécifiques et inexistantes chez les caféiers cultivés. La production de ces composés pourrait être due aux interactions des microorganismes endophytes et la plante hôte. Peu d'étude a été réalisée sur la richesse et la diversité des microorganismes associés à ces caféiers. L'objectif de cette étude est d'identifier les champignons endophytes isolés à partir des feuilles de quatre espèces de Mascarocoffea par la méthode morphologique et moléculaire. Quinze taxons ont pu être identifiés morphologiquement parmi les 30 isolés. Ce sont : Phyllosticta sp., Colletotrichum sp., Daldinia sp., Diaporthe sp., Cladosporium sp., Fusarium sp.01, Fusarium sp.02, Fusarium sp. 03, Monilinia sp., Trichoderma sp., Alternaria sp., Penicillium sp., Aspergillus niger, Rhizopus sp. et Nigrospora sp. Le phylum des Ascomycota est le mieux représenté avec 14 taxons et 1 taxon (Rhizopus sp.) appartient au phylum de Zygomycota. La caractérisation moléculaire a permis de confirmer l'identité de ces 15 taxons et celles des mycotaxons morphologiquement Non Identifiées (NI) dont Colletotrichum karstii, Colletotrichum siamense, Neofusicoccum parvum, Colletotrichum siamense, Punctularia strigosozonata, Stemphylium solani, Phoma multirostrata, Calophoma complonata, Daldinia vanderguchtiae, Phoma exigua et Boremia exigua. Cette étude nous a permis d'identifier les champignons endophytes des feuilles de Mascarocoffea de Madagascar.

Mots Clés : Champignons endophytes, diversité, Madagascar, Mascarocoffea

\section{INTRODUCTION}

The term Mascarocoffea was used by Chevalier (1938) to group wild coffee species endemic to Madagascar and neighbouring islands. These coffee trees are characterised by the absence of caffeine (Deng et al., 2017) and the presence of various specific phenolic and diterpene derivatives in their organs (Hamon et al., 2015). Previous studies demonstrated the involvement of fungal endophytes associated with Mascarocoffea in the synthesis of these metabolites (Ratsimbazafy, 2011; Andriamialiharisoa, 2011).

The diversity of endophytic fungi and their distribution in natural environments has been the subject of much work over the past decades. The majority of endophytic fungi isolated belong to the Ascomycota phylum and other taxa belong to the Zygomycota, Deuteromycota, Basidiomycota and the Oomycota phyla (Selim et al., 2017); with an estimated of 1.5 million species and an average of about 50 endophytic species per plant species (Vasundhara et al., 2019).
Most of the fungi described are species identified on the basis of colony morphology, hyphae and asexual and sexual reproductive structures (Rana et al., 2019). However, this identification is very complex (Hyde and Soytong, 2007) and is a hindrance to the progress of studies on these fungi. Due to this complexity or inefficiency, use of alternative studies such as molecular trait analysis has proven to be more efficient and reliable (Seifert, 2006). The objective of this study was to identify endophytic fungi isolated from the leaves of species of Mascarocoffea by morphological and molecular methods.

\section{MATERIALS AND METHODS}

Isolation and purification. Mature and healthy leaves of four Malagasy wild coffee species, Coffea perrieri, Coffea kianjavatensis, Coffea vianneyi and Coffea millotii, distributed in different phytogeographic areas, were collected (Table 1). Before being used for seeding, the collected leaves were washed gently with soapy water, rinsed thoroughly under tap water and then 
TABLE 1. Populations and species studied

\begin{tabular}{lllll}
\hline Scientific names & Number of population & \multicolumn{2}{c}{ Geographical description } \\
\cline { 3 - 4 } & & Site of origin & Phytogeography & Climate \\
\hline C. kianjavatensis & A213 & Kianjavato & Eastern Domain & Wet \\
C. perrieri & A305 & Ihosy & Southern Domain & Dry \\
C. vianneyi & A20 & Nosyvarika & Eastern Domain & Wet \\
C. millotii & A721 & Nosyvarika & Eastern Domain & Wet \\
\hline
\end{tabular}

with sterile distilled water to remove epiphytes and/or contaminants lining the leaf blade surface (Nefzi et al., 2018). They were then disinfected $(70 \%$ ethanol for 1 minute, then in sodium hypochlorite $(\mathrm{NaOCl}, 3 \%)$ for 4 minutes; and in $70 \%$ ethanol for 30 seconds (Suman et al., 2016b). Finally, the leaves were rinsed four times with sterile distilled water for one minute each and then dried on sterile filter paper under a laminar flow host (Khan et al., 2017).

Isolation was done according to the method described by Huang et al. (2007a). Sterilised leaves were cut into fragments of a few millimetres, at a rate of 5 to 6 segments per dish, and then placed in petri dishes containing a standard Potato Dextrose Agar (PDA) culture, previously autoclaved at $121{ }^{\circ} \mathrm{C}$ for 15 minutes, and supplemented with $150 \mathrm{mg}$ $\mathrm{l}^{-1}$ chloramphenicol to inhibit bacterial growth. The cultures were incubated in an oven at $25^{\circ} \mathrm{C}$ (Hazalin et al., 2009; Khan et al., 2010). Cultures were monitored daily for 15 days; each fungus developed on the twig fragments was isolated, purified by successive subculturing for identification and preserved on PDA pellet at $4^{\circ} \mathrm{C}$ and transplanted every 2 months (Pimentel et al., 2006). The percentage of colonisation was calculated in order to evaluate the rate of infection of the fragments by these microorganisms, using the following formula:

$$
\text { Colonisation }(\%)=\frac{\text { Total number of samples yielding }}{\text { Total number of samples in trial }} \times 100
$$

Morphological characterisation of endophytic fungi strains. Macroscopic identification was performed based on cultural characteristics (growth rate, thallus texture, colony colour, culture reverse, daylight medium and exudate). The fungi were also cultured on two other media, Czapek Yeast extract Agar (CYA) and Malt Extract Agar (MEA), at $25^{\circ} \mathrm{C}$ for seven days.

Microscopic identification of the endophytic fungal strains was done based on the morphological characters of hyphae: septation, coloration and reproductive forms: fruiting bodies, spore shapes and colours (Kim et al., 2013), and also referring to the identification the key of Barnett and Hunter (1998). Cultures were placed under extreme photon and thermal conditions to stimulate sporulation and facilitate identification. In the absence of sporulation, the strains were coded as Unidentified Fungi (NI) and the characteristics of the cultures such as general colony surface appearance, texture and hyphal pigmentation were taken into consideration (Suryanarayanan et al., 2002).

The abundance rate is calculated according to the following formula:

Number of fungal isolate taken $\mathrm{x}$ Number of fruiting fragments

Abundance $=$ x 100

Total number of fragments inoculated

Molecular identification of isolated endophytic fungi strains. DNA was extracted from young mycelium of isolated endophytic fungal strains according to the method 
developed by Moller et al. (1992) and amplified by the PCR method. The ITS (Internal Transcribed Spacer) region of the rDNA was amplified using a universal primer pair for ITS1/ITS4 fungi (Wali, et al., 2007). Their nucleotide sequences were respectively 5'TCCGTAGGTGAACCTGCGG ${ }^{3}$ ' and ${ }^{5}$ 'GCTGCGTTCTTCATCGATGC ${ }^{3}$. The amplification reaction was performed in a 50 $\mu \mathrm{l}$ reaction volume containing $25 \mu \mathrm{l}$ of $2 \mathrm{X}$ Taq DNA polymerase staining buffer, $1 \mu \mathrm{l}$ of forward primer (ITS1), $1 \mu \mathrm{l}$ of reverse primer (ITS2) and $22 \mu \mathrm{l}$ sterile water. The mixture was made for the total number of isolates and then split at $23 \mu \mathrm{l}$ per tube. Two ìl of DNA (50 $n g \mu l^{-1}$ ) was added last to the reaction mixture. DNA amplification was performed according to the following procedure (Sedra et al., 1998): pre-denaturation at $95^{\circ} \mathrm{C}$ for $3 \mathrm{~min}$ followed by 35 consecutive cycles of denaturation at $98{ }^{\circ} \mathrm{C}$ for $15 \mathrm{sec}$, specific hybridisation of the primers with the DNA template at $59{ }^{\circ} \mathrm{C}$ for $60 \mathrm{sec}$ and elongation at $72{ }^{\circ} \mathrm{C}$ for $2 \mathrm{~min}$. Finally, the last elongation phase was done at $72{ }^{\circ} \mathrm{C}$ for $10 \mathrm{~min}$.

The amplified products were sequenced by Macrogen Inc. using the same primers. The identity of the fungal sequences was determined by calculating similarity using the BLAST tool (Altschul et al., 1997). A similarity of $95 \%$ with a $90 \%$ overlap was selected for a sequence to appear in the results. The remaining non-sequenced isolates were grouped into taxa based on their morphological characters.

\section{RESULTS}

Mascarocoffea colonisation. Out of the 600 fragments of Mascarocoffea leaves inoculated, only 399 fragments were infected by endophytic fungi. A low infection rate of $57.34 \%$ was recorded in C. vianneyi and this rate did not vary throughout the culture. On the other hand, an infection rate of $82.67 \%$ was observed in $C$. perrieri on the third day of cultivation, while $C$. kianjavatensis and $C$. millotii species showed a colonisation rate of around 63\% (Fig. 1). These results suggest that the frequency of colonisation varies from one species to another.

\section{Morphological identification of isolated} species. Among the 399 infected fragments, thirty different mycotaxons were identified macroscopically and microscopically. These observations allowed the identification of 15 mycotaxons belonging to two different phyla: Ascomycota (14) and Zygomycota (1).

Among the Ascomycota, four classes were represented; namely Sordariomycetes,

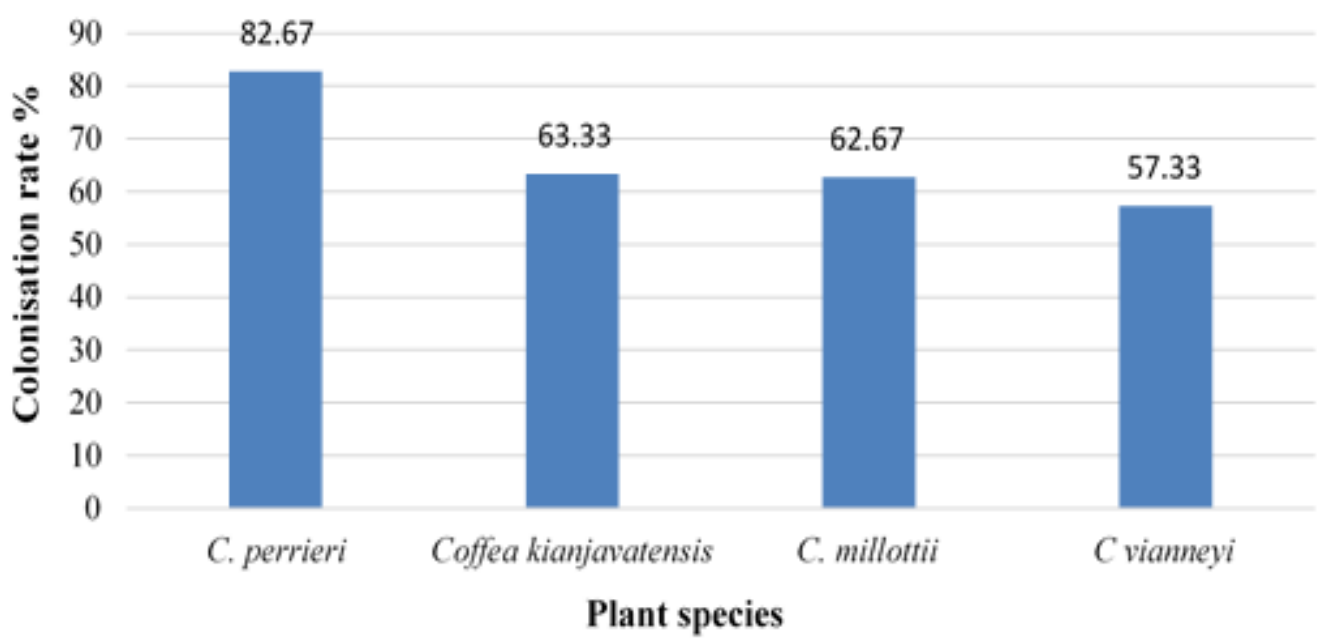

Figure 1. Colonisation rate of fragments of four collected species. 
Dothideomycetes, Eurotiomycetes and Leotiomycetes. The results obtained indicated that Sordariomycetes were the most abundant, represented by 6 genera: Fusarium (111 isolates), Trichoderma (39 isolates), Colletotrichum (33 isolates), Daldinia (18 isolates), Diaporthe (17 isolates) and Nigrospora (15 isolates). The Dothideomycetes were represented by 3 genera: Phyllosticta (43 isolates), Cladosporium (20 isolates) and Alternaria (8 isolates). Then, the Eurotiomycetes with two species Aspergillus niger and Penicillium sp. with, respectively 29 and 19 isolates. Finally, the Leotiomycetes were only represented by the genus Monilinia (6).

The Zygomycota were the least dominant and were represented by the genus Rhizopus (21 isolates). Fifty four isolates were not identified due to the difficulty encountered during microscopic examination (Table 2).

The study of the diversity of endophytes in the four species of coffee trees showed that Colletotrichum sp., Fusarium sp., Trichoderma sp., Aspergillus niger were present in each of them.

In $C$. kianjavatensis, the results showed the absence of Fusarium sp. 03 and Nigrospora sp. In the case of $C$. perrieri, three strains were completely absent, namely Cladosporium sp., Monilinia sp. and Rhizopus sp. Finally, an absence of four strains among the fifteen identified was observed in C. millotii (Daldinia sp., Diaporthe sp., Fusarium sp. 02, Alternaria sp.) and in C. vianneyi (Phyllosticta sp., Fusarium sp. 03, Monilinia sp., Penicillium sp.). It should also be noted that genus Fusarium was very abundant, it included three different species according to the result obtained: Fusarium sp.01, Fusarium sp. 02 and Fusarium sp. 03. Fusarium sp. 01 had the highest abundance of $C$. perrieri and $C$. millotii; while for $C$. vianneyi, Fusarium sp.02 was the most abundant. Unidentified isolates (UI) were found in all species studied (Table 3).
Molecular identification of isolates. Table 4 gives details of the fungal profiles obtained by morphological and molecular characterisation of 30 representative mycotaxa isolated from four wild coffee trees in Madagascar. Molecular analysis confirmed the identity of 10 isolated strains; namely Phyllosticta capitalensis, Colletotrichum Karstii, Diaporthe eres, Monilinia fructigena, Daldinia vanderguchtiae, Cladosporium asperulatum, Penicillim sp, Alternaria alternata, Fusarium tricinctum and Trichoderma sp.

The morphological identification of 06 strains, namely: Trichoderma sp., Fusarium sp. 02, Nigrospora sp., Rhizopus sp., Fusarium sp. 01 and Aspergillus niger, could not be confirmed molecularly.

Morphologically Unidentified (NI) strains were identified they included 14 species, namely: Colletotrichum karstii (2 species), Colletotrichum boninense, Colletotrichum siamense (3 species), Neofusicoccum parvum, Punctularia strigosozonata, Stemphylium solani, Phoma multirostrata, Calophoma complonata, Daldinia vanderguchtiae, Phoma exigua and Boremia exigua.

\section{DISCUSSION}

The results obtained confirmed the presence of endophytic fungi on the leaves of four species studied (Table 3). The importance of the presence of endophytic fungi on coffee leaves and more precisely on $C$. perrieri has already been demonstrated by Ratsimbazafy (2011). Hyde and Soytong (2008) showed that endophytes are ubiquitous in all plant species. These authors also showed that endophytes are best adapted to superficial tissues before colonising other plant tissues. They can conquer and grow in all leaf compartments individually, but often in community (Whipps et al., 2008).

According to the results obtained, the colonisation rates of endophytic fungi were 
TABLE 2. Taxonomic classification of endophytic fungi isolated from the leaves of four wild coffee species

\begin{tabular}{|c|c|c|c|c|c|c|c|}
\hline \multirow[t]{2}{*}{ Taxon } & \multirow[t]{2}{*}{ Endophytic mycotaxa } & \multirow{2}{*}{$\begin{array}{c}\text { Total number } \\
\text { of isolates }\end{array}$} & \multirow{2}{*}{$\begin{array}{c}\text { Abundance } \\
(\%)\end{array}$} & \multicolumn{4}{|c|}{ Classification of endophytic Mycotaxa } \\
\hline & & & & Phylum & Class & Order & Family \\
\hline 1 & Phyllosticta sp. & 43 & 7.15 & Ascomycota & Dothideomycetes & Botryosphaeriales & Botryosphaeriaceae \\
\hline 2 & Colletotrichum sp. & 33 & 5.49 & Ascomycota & Sordariomycetes & Phyllachorales & Phyllachoraceae \\
\hline 3 & Daldinia sp. & 18 & 2.99 & Ascomycota & Sordariomycetes & Xylariales & Hypoxylaceae \\
\hline 4 & Diaporthe sp. & 17 & 2.83 & Ascomycota & Sordariomycetes & Diaporthales & Diaporthaceae \\
\hline 5 & Cladosporium sp. & 20 & 3.32 & Ascomycota & Dothideomycetes & Capnodiales & Davidiellaceae \\
\hline 6 & Fusarium sp. 01 & 62 & 10.3 & Ascomycota & Sordariomycetes & Hypocreales & Nectriaceae \\
\hline 7 & Fusarium sp. 02 & 46 & 7.64 & Ascomycota & Sordariomycetes & Hypocreales & Nectriaceae \\
\hline 8 & Fusarium sp. 03 & 3 & 0.49 & Ascomycota & Sordariomycetes & Hypocreales & Nectriaceae \\
\hline 9 & Monilinia sp. & 6 & 0.99 & Ascomycota & Leotiomycetes & Heloliales & Sclerotinaceae \\
\hline 10 & Trichoderma sp. & 39 & 6.49 & Ascomycota & Sordariomycetes & Hypocreales & Hypocreaceae \\
\hline 11 & Alternaria sp. & 8 & 1.33 & Ascomycota & Dothideomycetes & Pleosporales & Pleosporaceae \\
\hline 12 & Penicillium sp. & 19 & 3.16 & Ascomycota & Eurotiomycetes & Pleosporales & Pleosporaceae \\
\hline 13 & Aspergillus niger & 29 & 4.83 & Ascomycota & Eurotiomycetes & Eurotiales & Trichocomaceae \\
\hline 14 & Rhizopus sp. & 21 & 3.49 & Zygomycota & Incertea sedis & Mucorales & Rhizopodaceae \\
\hline 15 & Nigrospora sp. & 15 & 2.49 & Ascomycota & Sordariomycetes & Trichosphaeriales & Trichosphaeriaceae \\
\hline 16 & NI & 54 & 8.97 & - & - & & - \\
\hline
\end{tabular}


TABLE 3. Abundance rate of endophytic fungi for each Mascarocoffea species

\begin{tabular}{|c|c|c|c|c|c|}
\hline \multirow[t]{2}{*}{ Taxon } & \multirow[t]{2}{*}{ Endophytic Mycotaxa } & \multicolumn{4}{|c|}{ Abundance (\%) } \\
\hline & & $\begin{array}{l}\text { Coffea } \\
\text { perrieri }\end{array}$ & $\begin{array}{c}\text { Coffea } \\
\text { kianjavatensis }\end{array}$ & $\begin{array}{l}\text { Coffea } \\
\text { millotii }\end{array}$ & $\begin{array}{l}\text { Coffea } \\
\text { vianneyi }\end{array}$ \\
\hline 01 & Phyllosticta sp. & 19.42 & 14.8 & 5.55 & 0 \\
\hline 02 & Colletotrichum sp. & 13.87 & 3.7 & 8.32 & 4.62 \\
\hline 03 & Daldinia sp. & 8.32 & 2.77 & 0 & 5.55 \\
\hline 04 & Diaporthe sp. & 3.7 & 10.17 & 0 & 1.85 \\
\hline 05 & Cladosporium sp. & 0 & 2.77 & 13.87 & 1.85 \\
\hline 06 & Fusarium sp. 01 & 28.67 & 6.47 & 15.72 & 6.47 \\
\hline 07 & Fusarium sp. 02 & 16.65 & 2.77 & 0 & 23.12 \\
\hline 08 & Fusarium sp. 03 & 1.85 & 0 & 0.92 & 0 \\
\hline 09 & Monilinia sp. & 0 & 4.62 & 0.92 & 0 \\
\hline 10 & Trichoderma sp. & 10.17 & 3.7 & 0.92 & 21.27 \\
\hline 11 & Alternaria sp. & 5.55 & 0.92 & 0 & 0.92 \\
\hline 12 & Penicillium sp. & 5.55 & 7.4 & 4.62 & 0 \\
\hline 13 & Aspergillus niger & 8.32 & 11.1 & 1.85 & 5.55 \\
\hline 14 & Rhizopus sp. & 0 & 3.7 & 12.95 & 2.77 \\
\hline 15 & Nigrospora sp. & 3.7 & 0 & 7.4 & 2.77 \\
\hline 16 & $\mathrm{NI}$ & 12.95 & 19.42 & 13.87 & 3.7 \\
\hline
\end{tabular}

different between host plants. This difference could be related to the problems of cultivation conditions (nutrient medium, temperature, surface sterilisation) that influence the colonisation of endophytic fungi (Gong and Guo; 2009) and/or by the nature of the plant species and the sampling area. In addition, the variation in daily atmospheric microflora concentration, as well as precipitation and strong winds vary from region to region and may be responsible for the difference in colonisation of endophytic fungi (Whipps et al., 2008). Physiological and/or biochemical factors such as salt stress, nutrient stress, and water stress must also be taken into consideration. Indeed, many authors show that the symbiotic association of the plant with endophytic fungi could be fundamental for plant survival, by helping to adapt to different stress conditions (Malinowski et al., 2006; Radhakrishnan et al., 2013; Ikram et al., 2020).
Morphological identification yielded a collection of 30 leaf-associated endophytic fungal isolates of the four different Mascarocoffea species. Among these 30 isolates, only 15 isolates could be identified. Indeed, the analysis of morphological criteria of the isolated microorganisms by macroscopic and microscopic observations is complex (Hyde and Soytong, 2007), generally due to the morphological similarities and especially the sterility of the endophytic fungi (Yeh and Kirschner, 2019). This last reason explains the non-identification of the other 15 isolates in this study.

Confirmation of the identity of endophytic fungal strains isolated from wild coffee leaves based on molecular analysis had not yet been the subject of previous work (Paulino De Moraes and Luchese, 2003; Martins et al., 2003; Taniwaki et al., 2003), which led to an incomplete identification of these species. In contrast with morphological identification, the 
TABLE 4. Comparison of the identification of endophytic fungi by morphological and molecular criteria

\begin{tabular}{|c|c|c|c|c|c|c|c|}
\hline \multirow[t]{2}{*}{ Number } & \multirow{2}{*}{$\begin{array}{l}\text { Morphological } \\
\text { identification }\end{array}$} & \multicolumn{6}{|c|}{ Molecular identification } \\
\hline & & Species & $\begin{array}{l}\text { Nucleotide } \\
\text { number }\end{array}$ & Query ID & Total score & $\begin{array}{c}\text { Accession } \\
\text { number } \\
\text { (GenBank) }\end{array}$ & $\begin{array}{l}\text { Percentage } \\
\text { of similarity }\end{array}$ \\
\hline 1 & Phyllosticta sp. & Phyllosticta capitalensis & 599 & Query_14921 & 1101 & KP900294.1 & $100 \%$ \\
\hline 2 & Colletotrichum sp. & Colletotrichum Karstii & 534 & Query_15373 & 968 & KY940478.1 & $99,44 \%$ \\
\hline 3 & Diaporthe sp. & Diaporthe eres & 524 & Query_36069 & 942 & MH931269.1 & $99,24 \%$ \\
\hline 4 & $\mathrm{NI}$ & Colletotrichum karstii & 535 & Query_14095 & 944 & MK569286.1 & $98,69 \%$ \\
\hline 5 & Monilinia sp & Monilinia fructigena & 488 & Query_45297 & 902 & LT615193.1 & $100 \%$ \\
\hline 6 & NI & Colletotrichum karstii & 535 & Query_14095 & 944 & MK569286.1 & $98,69 \%$ \\
\hline 7 & $\mathrm{NI}$ & Colletotrichum boninense & 531 & Query_7337 & 950 & KM520011.1 & $98,88 \%$ \\
\hline 8 & $\mathrm{NI}$ & Colletotrichum siamense & 510 & Query_56155 & 933 & MK984285.1 & $99,61 \%$ \\
\hline 9 & NI & Colletotrichum siamense & 510 & Query_20799 & 907 & MK984285.1 & $98,64 \%$ \\
\hline 10 & $\mathrm{NI}$ & Neofusicoccum parvum & 511 & Query_14635 & 856 & MN180877.1 & $96.42 \%$ \\
\hline 11 & NI & Colletotrichum siamense & 520 & Query_36049 & 952 & MK984285.1 & $99.62 \%$ \\
\hline 12 & Trichoderma sp. 01 & Trichoderma sp.01 & & & & & \\
\hline 13 & $\mathrm{NI}$ & Punctularia strigosozonata & 597 & Query_50615 & 1981 & MH558554.1 & $97,12 \%$ \\
\hline 14 & Daldinia sp. & Daldinia vanderguchtiae & 534 & Query_48581 & 965 & MH862910.1 & $99,25 \%$ \\
\hline 15 & Cladosporium sp & Cladosporium asperulatum & 491 & Query_22861 & 891 & MN202774.1 & $100 \%$ \\
\hline 16 & Penicillium sp. & Penicillium sp. & 514 & Query_12621 & 937 & GU270552.1 & $99 \%$ \\
\hline 17 & Fusarium sp. 02 & Fusarium sp. 02 & & & & & \\
\hline 18 & $\mathrm{NI}$ & Stemphylium solani & 533 & Query_54953 & 976 & KX025107.1 & $99,81 \%$ \\
\hline 19 & Nigrospora sp. & Nigrospora sp. & & & & & \\
\hline 20 & Alternaria sp. & Alternaria alternata & 516 & Query_23723 & 924 & KX988016.1 & $99,41 \%$ \\
\hline 21 & Fusarium sp. 03 & Fusarium tricinctum & 507 & Query_8727 & 928 & MN907441.1 & $100 \%$ \\
\hline 22 & $\mathrm{NI}$ & Phoma multirostrata & 487 & Query_65437 & 893 & AY943053.1 & $99,79 \%$ \\
\hline 23 & $\mathrm{NI}$ & Calophoma complonata & 561 & Query_11861 & 935 & JN624891.1 & $96,80 \%$ \\
\hline 24 & $\mathrm{NI}$ & Daldinia vanderguchtiae & 540 & Query_15601 & 983 & MH862910.1 & $99,63 \%$ \\
\hline
\end{tabular}


molecular method allowed us to characterise more precisely the taxa composing the fungal communities (Alamouti et al., 2007). The molecular identification of the present study allowed us to highlight the presence of 24 taxa of endophytic fungi from the leaves of four Mascarocoffea species. These are Colletotrichum karstii, Colletotrichum siamense, Fusarium tricinctum, Trichoderma sp., Phyllosticta capitalensis, Cladosporium asperulatum, Monilinia fructigena, Colletotrichum boninense, Calophoma complonata, Neofusicoccum parvum, Punctularia strigosozonata, Diaporthe eres, Daldinia vanderguchtiae, Penicillim sp, Alternaria alternata, Phoma multirostrata, Phoma exigua, Boremia exigua, and Stemphylium solani. All these fungal species have already been recorded as isolated endophytes in coffee leaves and roots (Oliveria et al., 2014; Saucedo-Garcia et al., 2014; Roberta et al., 2020). These taxa belong mainly to the phylum Ascomycota. This predominance of Ascomycetes has been reported as a characteristic of root and leaf endophyte communities (Angelini et al., 2012; Jha, 2019).

According to Senequier-Grozet and Canard (2016) regarding the general classification of endophytes, our strains would belong to the classes of endophytes 2-4 of the NonClavicipitaceae. These classes are characterised by their ability to grow in tissues above and below the soil, thus conferring tolerance to different types of environmental stress to infested plants (Rodriguez et al., 2008). In addition, the genera of endophytic fungi grouped in these classes have different types of interactions with plants, ranging from pathogenicity to symbiosis (Rodriguez et al., 2009), which explains the interest of their presence in Malagasy coffee leaves.

\section{CONCLUSION}

The present study has provided a more complete data on the diversity of endophytes associated with four species of wild coffee trees endemic to Madagascar. All selected 
Mascarocoffea plant species were harboured by endophytic fungi. The identification of these endophytes, based on morphological criteria, allowed the identification of the genus Phyllosticta sp., Colletotrichum sp., Daldinia sp., Diaporthe sp., Cladosporium sp., Fusarium sp.01, Fusarium sp. 02, Fusarium sp. 03, Monilinia sp, Trichoderma sp., Alternaria sp., Penicillium sp., Aspergillus niger, Rhizopus sp. and Nigrospora sp. The molecular techniques used allowed the identification most of the endophytic fungi species isolated. The majority of the isolates described in this study belong to the Ascomycota. Our study suggests that the ITS1 region of the rDNA is accurate for the identification of different species of endophytic fungi.

\section{ACKNOWLEDGMENT}

This work was financially supported by an Intra-ACP Mobility PIMASO and Doctoral Scholarship «Eugen Ionescu» by Agence Universitaire de la Francophonie (AUF).

\section{REFERENCES}

Altschul, S.F., Madden, T.L., Schäffer, A.A., Zhang, J., Zhang, Z., Miller, W. and Lipman, D.J. 1997. Gapped BLAST and PSI-BLAST: A New Generation of Protein Database Search Programs. Nucleic Acids Research 25(17): 3389-3402.

Andriamialiharisoa, R.F. 2011. Métabolites secondaires particuliers des feuilles de cinq populations de Mascarocoffea et des endophytes des feuilles de Coffea sp A315. Mémoire de DEA, Option BiotechnologieMicrobiologie, Faculté des Sciences, Université d'Antananarivo. 103pp.

Angelini, P., Rubini, A., Gigante, D, Reale, L., Pagiotti, R. and Venanzoni, R. 2012. The endophytic fungal communities associated with the leaves and roots of the common reed (Phragmites australis) in Lake Trasimeno (Perugia, Italy) in declining and healthy stands. Fungal Ecology 5(6): 683693.

Barnett, H.L. and Hunter, B.B. 1998. Illustrated genera of imperfect fungi. 4th ed. The American Phytopathological Society. 240pp.

Chevalier, A. 1938. Essai de regroupement systématique des caféiers sauvages de Madagascar et des îles Mascareignes. Revue de botanique appliquée et d'agriculture tropicale 18(208):825-843.

Deng, W.W., Rakotomalala, J.J., Nagai, C. and Ashihara, H. 2017. Caffeine biosynthesis and purine metabolism in leaves of Mascarocoffea species. European Chemical Bulletin 6(6): 223-228.

Gong, L.J. and Guo, S.X. 2009. Endophytic fungi from Dracaena cambodiana and Aquilaria sinensis and their antimicrobial activity. African Journal of Biotechnology 8(5):731-736.

Hamon, P., Rakotomalala, J.J., Akaffou, S., Razafinarivo, N., Couturon, E., Guyot, R., Crouzillat, D., Hamon, S. and de Kochko, A. 2015. Caffeine-free species in the genus Coffea. Coffee in health and disease prevention 5:39-44. http://dx.doi.org/ 10.1016/B978-0-12-409517-5.00005-X

Hazalin, N.A., Ramasamy, K., Lim, S.M., Wahab, I.A., Cole, A.L. and Abdul Majeed, A.B. 2009. Cytotoxic and antibacterial activities of endophytic fungi isolated from plants at the National Park, Pahang, Malaysia. BMC Complementary and Alternative Medicine 9(1): -5.

Huang, W.Y., Cai, Y.Z., Hyde, K.D., Corke, H. and Sun, M. 2007a. Endophytic fungi from Nerium oleander L (Apocynaceae): main constituents and antioxidant activity. World Journal of Microbiology and Biotechnology 23(9):1253-1263.

Hyde, K.D. and Soytong, K. 2007. Understanding microfungal diversity - a critique. Cryptogamie Mycologie 28:281289.

Hyde, K.D. and Soytong, K. 2008. The fungal endophyte dilemma. Fungal Diversity 33(163):e173. 
Ikram. M., Ali, N., Jan, G., Jan, F.G. and Khan, N. 2020. Endophytic fungal diversity and their interaction with plants for agriculture sustainability under stressful condition. Recent Patents on Food, Nutrition and Agriculture 11(2):115-123.

Jha, S. 2019. Endophytes and Secondary Metabolites. Springer, Gewerbestrasse 11. https:/doi.org/10.1007/978-3-319-76900-4

Khan, A.L., Gilani, S.A., Waqas, M., Al-Hosni, K., Al-Khiziri, S., Kim, Y.H. and Al-Harrasi, A. 2017. Endophytes from medicinal plants and their potential for producing indole acetic acid, improving seed germination and mitigating oxidative stress. Journal of Zhejiang University-Science B 18(2):125137.

Khan, R., Shahzad, S., Choudhary, M.I., Khan, S.A. and Ahmad, A. 2010. Communities of endophytic fungi in medicinal plant Withania somnifera. Pakistan Journal of Botany 42(2):1281-1287.

Kim, J.Y., Lee, S.Y., and Choi, H.S. 2013. Molecular and morphological identification of fungal species isolated from rice meju. Food Science and Biotechnology 22(3): 721-728.

Malinowski, D.P. and Belesky, D.P. 2006. Ecological importance of Neotyphodium spp. grass endophytes in agroecosystems. Grassland Science 52(1):1-14.

Martins, M.L., Martins, H.M. and Gimeno, A. 2003. Incidence of microflora and of ochratoxin A in green coffee beans (Coffea arabica). Food Additives and Contaminants 20(12):1127-1131.

Moller, E.M., Bahnweg, G., Sandermann, H. and Geiger, H.H. 1992. A simple and efficient protocol for isolation of high molecular weight DNA from filamentous fungi, fruit bodies, and infected plant tissues. Nucleic Acids Research 20(22): 6115.

Nefzi, A., Abdallah, R.A.B., JabnounKhiareddine, H., Ammar, N., Somai, L., Hamad, W., Haouala, R. and DaamiRemadi, M. 2018. Investigation on biosuppression of Fusarium crown and root rot of tomato (Solanum lycopersicum L.) and growth promotion using fungi naturally associated to Solanum linnaeanum L. African Journal of Microbiology Research 12(7):152-170.

Oliveira, R., Souza, R., Lima, T. and Cavalcanti, M. 2014. Endophytic fungal diversity in coffee leaves (Coffea arabica) cultivated using organic and conventional crop management systems. Mycophere 5(4):523-530.

Paulino De Moraes, M.H. and Luchese, R.H. 2003. Ochratoxin A on green coffee: influence of harvest and drying processing procedures. Journal of Agricultural and Food Chemistry 51(19):5824-5828.

Pimentel, I.C., Glienke-Blanco, C., Gabardo, J., Stuart, R.M. and Azevedo, J.L. 2006. Identification and colonization of endophytic fungi from soybean (Glycine max (L.) Merril) under different environmental conditions. Brazilian Archives of Biology and Technology 49: 705-711.

Radhakrishnan, R., Khan, A.L. and Lee, I.J. 2013. Endophytic fungal pre-treatments of seeds alleviates salinity stress effects in soybean plants. Journal of Microbiology 51(6):850-857.

Rana, K.L., Kour, D., Sheikh, I., Yadav, N., Yadav, A.N., Kumar, V., Singh, B.P., Dhaliwal, H.S. and Saxena, A.K. 2019. Biodiversity of endophytic fungi from diverse niches and their biotechnological applications. Advances in Endophytic Fungal Research 105-144.

Ratsimbazafy, T.T.Z.A. 2011. Relation entre spécificité chimique de Coffea perrieri population A305 (Mascarocoffea) et les endophytes de ses feuilles. DEA en Sciences de la Vie de l'Université d'Antananarivo. 93Pp.

Roberta, F., Adam R.M. and Marney, E.I. 2020. Root endophytes of coffee (Coffea arabica): Variation across climatic gradients 
and relationships with functional traits. Phytobiomes Journal 4:27-39.

Rodriguez, R.J., Henson, J., Van Volkenburgh, E., Hoy, M., Wright, L., Beckwith, F., Kim, Y. and Redman, R.S. 2008. Stress tolerance in plants via habitat-adapted symbiosis. International Society for Microbial Ecology 2(4):404-416.

Rodriguez, R.J., White Jr, J.F., Arnold, A.E. and Redman, R.S. 2009. Fungal endophytes: diversity and Functional roles. New Phytologist 182(2):314-330.

Saman, A., Yadav, A.N. and Verma, P. 2016. Endophytic microbes in crops: diversity and beneficial impact for sustainable agriculture. In Microbial inoculants in sustainable agricultural productivity. Springer, New Delhi 117-143.

Saucedo-Garcia, A., Anaya, A.L., EpinosaGarcia, F.J. and Gonzalez, M.C. 2014. Diversity and communities of foliar endophytic fungi from different agroecosystems of Coffea arabica $\mathrm{L}$. in two region of Veracruz, Mexico. PloS one 9(6):e98454.

Sedra, M.H., Lashermes, P., Trouslot, P., Combes, M.C. and Hamon, S. 1998. Identification and genetic diversity analysis of date palm (Phoenix dactylifera L.) varieties from Morocco using RAPD markers. Euphytica 103(1):75-82.

Seifert, K.A. 2006. Enhancing the relevance of fungal taxonomy to plant pathology: phylogenetics, molecular diagnostics, and long-term memory. Canadian Journal of Plant Pathology 28(S1):280-287.

Selim, K.A., Nagia, M.M. and Ghwas, D.E.E. 2017. Endophytic fungi are multifunctional biosynthesizers: Ecological role and chemical diversity. Endophytic fungi: diversity, characterization and biocontrol. Nova Science Publishers 2:39-91.

Senequier-crozet, A. et Canard, B. 2016. Les champignons endophytes : Impact sur les écosystèmes et production de molécules d'intérêt thérapeutique. Thèse de doctorat, Faculté de Pharmacie, Université de Grenoble Alpes, France. 92pp.

Suryanarayanan, T.S., Murali, T.S. and Venkatesan, G. 2002. Occurrence and distribution of fungal endophytes in tropical forests across a rainfall gradient. Canadian Journal of Botany 80(8):818-826.

Taniwaki, M.H., Pitt, J.I., Teixeira, A.A. and Iamanaka, B.T. 2003. The source of ochratoxin A in Brazilian coffee and its formation in relation to processing methods. International Journal of Food Microbiology 82(2):173-179.

Vasundhara, M., Reddy, M.S. and Kumar, A. 2019. Secondary metabolites from endophytic fungi and their biological activities. New and future developments in microbial biotechnology and bioengineering. pp. 237-258.

Wali, P.R., Ahlholm, J.U., Helander, M. and Saikkonen, K. 2007. Occurrence and genetic structure of the systemic grass endophyte Epichloe festucae in fine fescue populations. Microbial Ecology 53(1):20.

Whipps, J.M., Hand, P., Pink, D. and Bending, G.D. 2008. Phyllosphere microbiology with special reference to diversity and plant genotype. Journal of Applied Microbiology 105(6):1744-1755.

Yeu, Y.H. and Kirschner, R. 2019. Diversity of endophytic fungi of the costal plant Vitex rotundifolia in Taiwan. Microbes and Environments 34(1):59-63 